\title{
AZ INFORMÁCIÓS-KOMMUNIKÁCIÓS TECHNIKÁK TERJEDÉSÉNEK REGIONÁLIS KÜLÖNBSÉGEI MAGYARORSZÁGON
}

\author{
(Regional Disparities in the Spreading of \\ Information-Communication Technologies in Hungary)
}

\author{
KANALAS IMRE
}

\section{Bevezetés}

Az 1980-90-es évek fordulóján még csak nagyon kevesen gondolták, hogy rövid tíz év leforgása alatt olyan új infrastrukturális hálózat s olyan új technika, technológia áll majd a közigazgatás, a vállalkozások, a nonprofit szféra és az állampolgárok rendelkezésére, amely újabb dimenziókat nyit meg a társadalmi kommunikáció, az információközlés és információszerzés - amúgy sem szük - területén.

Az ágazat jelentőségére, az információátvitelnek, a hírközlésnek és a számítástechnikának minden tevékenységbe behatoló, átformáló elöretörésére már az 1980-as évek elején felhívták a figyelmet a hazai kutatók. Megállapították, hogy a műszaki fejlődés által támasztott új versenyhelyzet kihívásaira Magyarorszảgnak is gyorsan reagálnia kell (Vámos 1981). Sajnos a kihívásra adott válaszok és szükséges intézkedések - az ismert politikai és gazdasági környezet következtében majdnem egy évtizedet késtek, így az információs-kommunikációs technológiák területén Magyarország fáziskésésbe került. Erdősi Ferenc szerint: „Hátrányunkból azonban bizonyos elönyt is kovácsolhatunk, amennyiben fel tudunk készülni a Föld fejlettebb régióiban már kibontakozó információs gazdaságban és társadalomban felmerülő újszerủ kérdések megválaszolására. Ugyan a hazai fejlődés adottságaink miatt részleteiben nem fogja teljesen a Nyugatot követni, a főbb vonások hasonlósága azonban várható." (Erdósi 1992)

Az Információs Társadalomba vezető úton Magyarországnak számos nehézséggel kellett ill. kell megküzdenie. A jövőbeli társadalmi, gazdasági és területi fejlődésünket nagymértékben az fogja meghatározni, hogy az egyes térségeink miképpen tudnak majd reagálni az Információs Kor kihívásaira. Fontos kérdés lesz, hogy a tágabb értelemben vett információ elérése és birtoklása minden területi szintnek és társadalmi rétegnek megadatik-e, vagy egy újfajta egyenlötlenségi folyamatnak, egyfajta - az információ birtoklásán alapuló - XXI. századi centrum-periféria viszonylat kialakulásának leszünk-e tanúi? Annak érdekében, hogy ezeket a kedvezötlen folyamatokat elkerüljük, s sikerrel kezdhessük meg a felzárkózást az „információ gazdagok táborába”, számos területen jelentős elörelépésre lenne szükség.

A legfontosabb megoldandó feladatok a következők lennének:

- A jelen és a közeljövő kihívásainak felismerése, megfelelő stratégiai programok kidolgozása. 
- Széles konszenzuson alapuló társadalmi, gazdasági és politikai támogatottság.

- A társadalom felvilágosítása és felkészítése az Információs Kor által támasztott új kihívások fogadására. Ösztönző és érdekeltségi rendszerek kialakítása az önkormányzatok és a kormányzat részéröl.

- Az oktatás kiemelt támogatása (különösen nagy figyelmet fordítva a tehetségre, kreativitásra, szorgalomra és a folyamatos tanulás szükségességére).

- A társadalmi fogadókészség, a nyitottság kialakitása, erósítése.

- Az információkhoz történő hozzáférés, az elérhetőség feltételeinek kialakítása, javítása (olcsóbb szolgáltatás, hálózat kiépítés stb.)

- A távközlési piac liberalizálása.

- A ,tartalomipar” kiépítése, erősítése.

- És végül, de nem utolsó sorban a távközlési- és informatikai infrastruktúra valamint a müszaki háttér folyamatos fejlesztése, a gyengén ellátott területeken a hálózat kialakítása.

Néhány területen már jelentős lépések történtek nemzetközi hátrányunk felszámolása érdekében. A felsorolt tényezők közül tanulmányunkban most - a legutóbbi pontot - az elérhetöséget, az információ fogadását - ma még - talán leginkább meghatározó informatikai infrastruktúra, valamint számítógépes háttér hazai fejlödését és területi kiépülését szeretnénk bemutatni.

\section{A magyarországi informatikai infrastruktúra kialakulása és fejlödése}

Az elmúlt közel másfél évtized során Magyarországon az informatikai hálózatnak három jól elkülöníthető szintje alakult ki. Ezek közül az egyik legjelentösebb felhasználói számmal, a legnagyobb adatforgalommal, s talán az alkalmazások szempontjából a legnagyobb jelentőséggel a HBONE (Hungarian Backbone) hálózat bír, ami a kutatási, fejlesztési, felsőoktatási, könyvtári és közgy̋̋jjteményi közösség számítógép-hálózati infrastruktúrája. A második szintet az 1997 óta - hol gyorsabban, hol lassabban - bővülö magyarországi középiskolai informatikai hálózat képezi, amely a Sulinet program keretében épült ki, míg a harmadik szintet a legdinamikusabban fejlödö, s a legtöbb mủszaki megoldást alkalmazó kereskedelmi adatkommunikációs hálózatok jelentik.

\section{A HBONE hálózata}

A magyarországi számítógépes hálózat fejlesztése 1986-ban, a Magyar Tudományos Akadémia és az Országos Müszaki Fejlesztési Bizottság által indított Információs Infrastruktúra Fejlesztési Program (IIFP) keretében indult el, hazai (MTA, OMFB, OTKA, MKM) valamint külföldi (világbanki és európai közösségi) források felhasználásával. A program célja az volt, hogy létrehozza a hazai „academic" (kutatási, fejlesztési, felsőoktatási, könyvtári és közgyưjteményi) közösség számítógép-hálózati infrastruktúráját, valamint biztosítsa a fejlett világ információtechnológiai színvonalát és szolgáltatásait a hazai felhasználók körében. A hálózat- 
fejlesztés első fázisa 1986-tól 1990-ig tartott, melynek keretében kialakult az alapvetö információs infrastruktúra. A magas szintủ technológiảkra, berendezésekre és eszközökre vonatkozó nyugati embargó megnehezítette ugyan a hálózat gyors kiépitését, de a hazai fejlesztéseknek köszönhetően az 1980-90-es évek fordulóján a magyar kutatói-felsőoktatási közösség intézményei között egy X.25-ös hálózaton keresztül lehetövé vált a csomagkapcsolt adatszolgáltatás. A nemzetközi adatkommunikációs szabványok (X.25, XXX, UUCP) alkalmazásával, valamint a nyugatihoz hasonló számítógépes szolgáltatások (elektronikus levelezés, faliújság-elérés, fájl-átvitel) biztosításával pedig létrejöttek a müszaki feltételei a nemzetközi kutatói és felsőoktatási informatikai hálózatokkal való közvetlen információcserének. Ennek eredményeként 1990 legelején a magyar kutatói-felsőoktatási közösség csatlakozott az EUnet hálózatához, majd ezt követően az amerikai BITNET hálózat európai leágazásához, az EARN-höz. A COCOM korlátozások eltörlése után tovább folytatódott a magyarországi hálózat korszerüsítése, új kapcsolóközpontok, mikrohullámú és optikai összeköttetések jöttek létre a rendszer kiemelt fontosságú csomópontjain. Az 1991. évi Internethez történő csatlakozásunkat követően - az IIF közremüködésével - létrehozták az IP (Internet Protokol) technológiára épülö magyarországi oktatási és kutatási célú gerinchálózatot, a HBONE-t (1993). A további fejlödést nagyban meghatározta, hogy - a nemzetközi hálózati kapcsolataink bövítése, valamint a nemzetközi hálózati szervezetekben történő részvételünk elösegítése érdekében - a felsőoktatási, közgyüjteményi és kutatói közösség 1992-ben megalakította a HUNGARNET Egyesületet. Az Egyesület munkájának köszönhetöen Magyarország az 1990-es évek folyamán meghatározó nemzetközi szervezeteknek (TERENA, DANTE, CEENet, ISOC) ${ }^{1}$ lett a tagja. A nemzetközi együttmüködéseken keresztül pedig jó néhány meghatározó projekt (pl. TEN-34, TEN-155, Internet 2, EK 5. keretprogram) részese lehetett, illetve lehet. A kilencvenes évek közepén az egyre növekvő hálózati forgalom, a mind jobb minőségü szolgáltatásokhoz történő hozzáférés, a nemzetközi információhálózati kapcsolataink zavartalan biztosítása (pl. EuropaNET, Ebone) és egy nemzetközi színvonalú informatikai hálózat kiépítése érdekében szükségessé vált egy új nemzeti program, a NIIFP, beindítása (1995). A program keretében tovább folytatódott a HUNGARNET egyesület tagintézményeinek csatlakoztatása a HBONE hálózathoz. Az extenzív fejlödésnek köszönhetően - amely jelentös müszaki fejlesztéseket is hozott - az elmúlt közel egy évtizedben ötszörösére növekedett a hálózatba bekapcsolt intézmények száma. Napjainkban 26 regionális központon keresztül 47 város mintegy 1000 intézményében kb. 70000 host (Internet végpont) gép áll az ,academic” közösség rendelkezésére. A felhasználói kör jelentös bővülése - 1994-ben 30000 fö, 1996-ban 100000 fö, míg 2000 elején több mint 230000 fö - a hazai és a nemzetközi hálózati forgalom ugrásszerü növekedését eredményezte, így szükségessé vált a nemzetközi konnektivitásunk bővítése. Ennek érdekében a kilencvenes évek elejére jellemző 64 Kbit/s sávszélességü európai összeköttetésünket (Ebone-Bécs) folyamatosan növeltük elöször 2x64 Kbit/s-ra, majd 1995-ben $256 \mathrm{Kbit} / \mathrm{s}$-ra. Ugyanebben az évben a HUNGARNET Egyesület $2 \mathrm{Mbit} / \mathrm{s}$-os hozzáféréshez jutott az EuropaNET 
(Amszterdam) felé, melyből a HBONE $1 \mathrm{Mbit} / \mathrm{s}-$ os sávszélességgel rendelkezett. A hazai regionális központok közötti hálózati kapcsolatokra ez idő tájt a $64 \mathrm{Kbit} / \mathrm{s}-$ $256 \mathrm{Kbit} / \mathrm{s}-$ os bérelt vonalas összeköttetések voltak jellemzőek, míg a budapesti HBONE központ csomópontjai között $100 \mathrm{Mbit} / \mathrm{s}$ optikai, $10 \mathrm{Mbit} / \mathrm{s}$ Ethernet és 2 Mbit/s mikrohullámú vonalak tartották a kapcsolatot. Az évtized második felében a hazai hálózati fejlesztések felgyorsultak. A regionális HBONE központjaink között folyamatosan bővítették a hálózati sávszélességeket, s a nemzetközi konnektivitásunk is lényegesen javult a TEN-34 EU projekt keretében üzembe helyezett ATM alapú 10 Mbit/s-os (1997. május), majd a TEN-155 program keretében megvalósított $34 \mathrm{Mbit} / \mathrm{s}-0$ (17-34 Mbit/s EU, $17 \mathrm{Mbit} / \mathrm{s}$ USA) (1999. február) Internet kapcsolatnak köszönhetỏen. A kialakított HBONE hálózatról elmondható, hogy európai színvonalú, s a hazai igényeket - egyelöre - ki tudja elégíteni. Problémát jelent azonban, hogy az évente duplázódó adatforgalom és az erőforrásokat sem kímélö magas szintü szolgáltatások rövid időn belül szükössé teszik a meglévő kapacitásokat. A hazai hálózati szolgáltatás minőségét és a forgalom egyenletes növekedését a jövőben nagymértékben meg fogja határozni, hogy sikerül-e folytatni a hálózati fejlesztések területén az elmúlt évekre jellemző dinamikát? Folytatódik-e a hálózati eszközök és berendezések korszerúsítése? Megvalósul-e a regionális központok közötti nagysebességü (10-155 Mbit/s) gerinchálózat kialakítása? Lesze pénz a nagyobb megbízhatóságot eredményező tartalékeszkőzök beszerzésére és üzembe helyezésére valamint - a Budapestet elkerülö - tartalék hálózati útvonalak kialakítására?

\section{A Sulinet hálózata}

A magyarországi „Középiskolai Internet Program” (Sulinet) 1996 szeptemberében indult a Mủvelödési és Közoktatási Minisztérium támogatásával. A fizikai hálózat kiépítése azonban csak 1997 folyamán kezdỏdött el - egy konzorcium megbízásából - több koncessziós telefontársaság (LTO-k) bevonásával. A megvalósítás során több mint 300 település 1526 intézménye (középiskolák, kollégiumok, általános iskolák) került a Sulinet hálózatára, melyek közuil 1217 közoktatási intézmény (kb. 65\%-a középiskola). A kialakított hálózat két szintre tagozódik. Az elsó szint a gerinchálózati rész - biztosítja a regionális csomóponti és külföldi csatlakozást, amely közvetlenül a MATÁV optikai gyủrüjéhez kapcsolódik. A második szint - a felhordóhálózat - az iskolák és a gerinchálózat között teremt kapcsolatot. A nagyobb (500 fő fölötti) iskolák általában $64 \mathrm{Kbit} / \mathrm{s}$ sebességü ISDN, míg az ennél kisebb intézmények ugyanilyen sebességü modemes kapcsolatot alakíthattak ki. A Sulinet gerinchálózatát egy $2 \mathrm{Mbit} / \mathrm{s}$-os optikai szál képezi, amely összeköti a központi router-eket (forgalom-irányító kapcsológépek) a régiókkal. A nemzetközi konnektivitás a Hungarneten keresztül valósul meg. Ez a kapcsolat 1999 elejéig egy $800 \mathrm{Kbit} / \mathrm{s}-0$ s vonalat jelentett a TEN-34 európai hálózat felé, valamint egy tengeren túli összeköttetést $512 \mathrm{Kbit} / \mathrm{s}-$ os sảvszélességgel. Jelentősebb kapacitásnỏvekedés az 1999 februári TEN-155-ös csatlakozásunkkal következett be, amikor 
a nemzetközi hálózati sávszélesség 4,5 Mbit/s-ra bỏvült. A Sulinet program a hálózati fejlesztéseknek köszönhetően napjainkban több mint 500000 diáknak és tanárnak teszi lehetővé az Interneten elérhető legfrissebb információkhoz történő hozzáférést. A számottevő eredmények ellenére azonban meg kell jegyeznünk, hogy miután a Sulinet programot leállították, ill. átalakították, a fejlödés lendülete megtorpant, így csak 2002-re várható az általános iskolák teljes körének csatlakozása az Internethez.

\section{A kereskedelmi hálózatok}

$\mathrm{Az}$ adatátvitelre alkalmas hálózatok Magyarországon már a nyolcvanas évek második felétől megjelentek, nagyobb arányú kiépítésük azonban a magasabb szintü szolgáltatások iránti alacsony kereslet és a hálózat kiépitéséhez szükséges tỏke hiánya miatt késlekedett. A távközlés és adatkommunikáció területén mutatott infrastrukturális elmaradottságunkra jellemző volt, hogy még az 1990-es évek elején is a települések közötti - és a településeken belüli - hálózat zömét kisteljesítményú rézkábelek biztosították. ${ }^{2}$ A központok nagyobb részt analóg rendszerüek voltak, de elöfordultak olyan települések is, ahol manuális kezelésủ központok üzemeltek. Az emeltszintủ adatkommunikációs szolgáltatásokhoz nélkülözhetetlen digitális központok elterjedtsége ekkor még nem volt számottevő. ${ }^{3} \mathrm{Az}$ igazi áttörés a hálózat kiépitésében és minöségének javításában, a hagyományos - manuális és analóg telefonközpontok korszerú digitális központokra történő lecserélésében illetve építésében csak a kilencvenes évek közepén, a távközlési piac privatizációjával következett be. A koncessziós távközlési társaságok (LTO-k) megalakulásukat követöen gyors ütemben fogtak hozzá távközlési és adatkommunikációs hálózataik kiépítéséhez és korszerüsitéséhez. ${ }^{4} \mathrm{~A}$ fejlesztések első fázisában a legfontosabb szempont az elöfizetők számának jelentős bővítése volt, ezért erőltetett ütemben épültek ki a végfelhasználói hálózatok. ${ }^{5} \mathrm{Az}$ Internetes és adatkommunikációs szolgáltatások ezekben az években - jellemzöen - egyszerü telefonvonalon, X.25-ös és alacsony sebességú bérelt vonalakon valósultak meg. A kilencvenes évek második felében a fejlesztések súlypontja megváltozott. Az adatátvitel és az uzleti kommunikáció dinamikus fejlődése, valamint a távközlési szolgáltatások szinvonalának emelése érdekében a ,hálózati képesség" (nagyobb kapacitás, jobb minőségü adatátvitel, $S D H, A T M$ technológiák, biztonságosabb hálózatok) növelésére helyezödött a hangsúly (Nagy 1997). Ennek érdekében egyre több távközlési csomópontban helyeztek üzembe új digitális központokat, ezáltal a digitális kapcsolás aránya 1999 elején meghaladta a $80 \%$-ot. Tovább folytatódott a már meglévő távközlési gerinchálózat valamint a településeken belüli hálózatok korszerüsítése és bövítése. ${ }^{6}$ A fejlesztések eredményeként a legnagyobb koncessziós szolgáltató, a MATÁV, két világszínvonalú nemzetközi kapcsoló központ, valamint SDH (Szinkron elvü Digitális Hierarchia) technológián alapuló átvitel-technikai berendezésekkel felszerelt, az országhatárt 11 helyen átlépỏ optikai kábelek tulajdonosa lett. Az LTO-k közötti jobb hálózati kommunikáció érdekében a MATÁV hálózatát X.25-ös kapcsolatok kötik 
össze 83 más hálózattal, míg az ISDN révén további 30 hálózathoz csatlakozik. A nemzetközi konnektivitást a Globális Európai Hálózathoz (GEN) történỏ csatlakozás biztosítja, amely egy nemzetközi bérelt vonalakat nyújtó, nagykapacitású integrált hálózatirányítási rendszer.

A koncessziós telefontársaságok mellett - az 1992-es távközlési törvény óta - a szabad piaci területekre betörỏ alternatív távközlési társaságok is - készülve már a 2002-es távkőzlési liberalizációra - jelentős hálózatfejlesztéseket hajtottak végre. Az Antenna Hungária Rt. kialakitott egy 51 csomópontot összekötő mikrohullámú hálózatot. A GTS Magyarország Kft. Budapesten épített ki egy $120 \mathrm{~km}$ hosszú optikai gerinchálózatot, ezen kívül 46 csomóponttal rendelkező mikrohullámú hálózat tulajdonosa. A Novacom Távközlési Kft. egyelöre az ELMÜ és az ÉMÁSZ áramszolgáltatók távközlési hálózatát bérli, de kidolgozta azt a technikát, amely segítségével az elektromos hálózatokon keresztül juttatja majd el a távközlési jeleket a háztartásokba. ${ }^{7}$ A PanTel Rt. a MÁV nyomvonalai mellett 1999 végére több mint 2000 km hosszú optikai hálózatot fektetett le, ami hamarosan 3000 km-re bỏvül, s gyakorlatilag országos lefedettséget ér el. A felsorolt társaságok hálózatain kívül említést kell tennünk még a négy koncessziós mobil telefontársaság (Westel 900, Pannon GSM, Westel Rádiótelefon Kft., Vodafone) és a kábeltévészolgáltatók hálózatairól is. Elöljáróban megjegyzendő, hogy sem a mobil rendszerek, sem a kábeltévés rendszerek egyelöre nem játszanak olyan szerepet az adatkommunikáció és Internet szolgáltatás területén, mint amilyent elterjedtségük és kiépitettségük feltételezne. A mobil szolgáltatók az elmúlt években jelentős fejlesztéseket végrehajtva elérték, hogy országosan $98-99 \%$-os lefedettséget $\mathrm{s}$ emelt szintủ szolgáltatásokat (pl. SMS, Internet) tudnak biztosítani ügyfeleiknek. ${ }^{8}$ Gyakorlatilag a teljes lefedettség ellenére (1999-ben) a több mint 1,5 millió elöfizető töredéke (kb. 5000 fö) tartott csak igényt Internetes adathálózati szolgáltatásra, ami elsősorban a magas szolgáltatási díjjal és a két mobiltelefon-rendszer (NMT, GSM) müszaki korlátjaival (pl. szük sávszélesség) magyarázható.

A Hírközlési Föfelügyelet által is engedélyezett kábeltévés rendszerek Magyarországon több mint 500 településen, mintegy 1,5 millió háztartásban találhatók meg. A modern csillagpontos kiépítésú (a kétirányú adatforgalmat lehetővé tevő) kábeltévés hálózatok műszaki jellemzői lényegesen kedvezőbbek, mint a ma használatos mobil vagy hagyományos telefonvonalak. ${ }^{9}$ A müszaki jellemzökön kívül nem elhanyagolható olcsóságuk sem, hiszen a szolgáltatás során nem kell külön telefondíjat fizetni. Érthetö tehát, hogy napjainkban egyre több településen (pl. Budapest, Pécs, Dunaújváros) terjedtek el a kábeltévés rendszereken kínált adathálózati és bérelt vonali szolgáltatások. ${ }^{10} \mathrm{~A}$ kedvező lehetőségek ellenére a kábeltévé-hálózaton keresztül történő Internethasználat nagyobb arányú elterjedését két fö tényező akadályozza. Az elsỏ egy múszaki jellegủ probléma, nevezetesen az, hogy a hálózat 50\%-a nem csillagpontos kiépítésủ, így nem is alkalmas kétirányú adatforgalom ellátására. A második probléma egyrészt jogi, másrészt gazdasági természetú, hiszen a távközlési törvény értelmében a 30000 fönél népesebb településeken a már telefonvonalakkal rendelkezö távközlési társaságok nem épithetnek kábeltévé-hálózatot, 
továbbá egy cég a kábeltévés piac maximum $1 / 6$ részét ellenőrizheti. ${ }^{11}$ Így az a furcsa helyzet állt elő, hogy azok a tőkeerös vállalkozások, amelyek a hálózat kiépítéséhez, fejlesztéséhez szükséges forrásokkal rendelkeznének - lehetőségeik ellenére - csak a törvényi keretek között fejleszthetnek. A kisebb kábeltévéhálózatok pedig saját forrásból nem tudnak olyan minőségủ rendszert kialakítani, amely alkalmas lenne kétirányú adatforgalom biztosítására.

Az adatkommunikáció infrastruktúráját tekintve a felsoroltakon kívül (vezetékes és rövidhullámú jeltovábbítás) még egy átviteli mód ismeretes, a mủholdakon keresztül történő adatátvitel, az úgynevezett VSAT (Very Small Aperture Terminal) szolgáltatás. Ennek a müszaki megoldásnak a legnagyobb elönye az üzleti kommunikáció számára nélkülözhetetlen kiváló minőség és nagyfokú megbízhatóság. További előnyként említhető, hogy a rendszer egy- és kétirányú adatkommunikációt egyaránt lehetôvé tesz, a technológiából adódóan pedig akár kontinensnyi területek lefedésére is alkalmas. A nyugati országokhoz hasonlóan a szolgáltatás hazánkban is terjedóben van, így a VSAT szolgáltatók termináljainak száma napjainkban meghaladja a 3000-et. Az elöfizetők elsősorban több telephelyes vállalatok, bankok, kereskedelmi hálózatok stb.

Összefoglalva megállapítható, hogy a magyarországi informatikai infrastruktúra három jól elkülönithetỏ szintre (HBONE, Sulinet, kereskedelmi hálózatok) tagolható. A hálózatok múszaki jellemzői és az alkalmazott adatátviteli technikák - az elmúlt több mint tíz év fejlesztéseinek köszönhetően - közelítenek az európai normákhoz, így a kiépített területeken kielégitő feltételét tudják biztosítani a magyarországi informatikai szolgáltatások minél szélesebb felhasználói körhöz történő eljuttatásának. ${ }^{12} \mathrm{~A}$ jelentős fejlesztések ellenére azonban meg kell jegyeznünk, hogy ma az ország területén az adatkommunikációs-hálózat kiépítési-mủködtetési elve a rentabilitás mentén írható le, ezért kizáró jellegủ. Elsősorban azokon a területeken vehetők igénybe a magas szintủ adatkommunikációs szolgáltatások, ahol a digitális hálózatok rendelkezésre állnak. A digitális hálózatok elterjedése azonban - az alacsonyabb népességszám, a szerényebb gazdasági teljesítmény, a vállalkozások alacsony száma illetve a felhasználói igények visszafogottsága vagy hiánya miatt rendkívül egyenlötlen, még napjainkban is találhatunk olyan primer körzeteket, ahol a központkapacitás digitalizáltsága nem haladja meg az 50\%-ot (pl. bajai primer körzet $24 \%$, szentesi primer körzet $42 \%$ ). ${ }^{13}$ Megállapítható tehát, hogy a müszaki-technikai hálózatok kiépítése/kiépülése is - különösen az Információs Társadalom küszöbén - differenciáló tényezöként hathat a területek közötti versenyben. Ezzel a veszéllyel szembe kell néznünk annak ellenére, hogy a müszaki-technikai alapok a tudományos kutatás, a müszaki újítások (mobil kommunikáció, mobil internetezés [WAP], alternatív adatkommunikációs megoldások [pl. PLC]), valamint a tudatos fejlesztési politika következtében kiteljesed(het)nek. 


\section{A magyarországi Internetes állapot nemzetközi összehasonlításban}

Az elmúlt évtized hazai adatkommunikációs fejlődéséröl akkor alkothatunk reális képet, ha rendelkezünk valamilyen viszonyítási alappal. A kilencvenes évek során szinte az egész világon óriási robbanás következett be a távközlés és adatkommunikáció piacán. Napjainkra az információs-kommunikációs ipar a legdinamikusabban növekedő húzóágazattá vált. Az ICT piacnak is nevezett ágazat éves forgalma világszinten (1998-ban) elérte az 1445 milliárd ECU-t, éves átlagos fejlödési üteme pedig 10\% körüli, ezzel jóval meghaladja az összes többi iparág azonos mutatóját.

Magyarországon az info-kommunikációs ágazat éves növekedése a nemzetközi irányszámokat is meghaladó mértékben bővült az elmúlt évtizedben. A dinamikus fejlödés hátterében sok szakember a gyengébb ellátottság felszámolására történő kísérletet látja. Ugyanezen időszak alatt jól nyomon követhető az adatkommunikációs hálózatok sávszélességének növelése és minőségük javítása is. Ennek köszönhetően az „academic” hálózat néhány csomópontja (pl. Budapest, Gödöllö, Szeged, Veszprém) már 155 Mbit/s-os sávszélességgel csatlakozik a HBONE gerinchálózatához, ami a nyugat-európai kutatói hálózatok teljesítményével azonos. ${ }^{14} \mathrm{Az}$ Internetes ellátottság tekintetében is elkezdődött felzárkózásunk a fejlett országokhoz. A kilencvenes évek közepéhez képest sikerült csökkenteni a hátrányunkat az 1000 före jutó domain név szerverek, s különösen az Internet végpontok (host) számának vonatkozásában. Míg az évtized közepén az 1000 lakosra jutó host számítógépek számában átlagosan 15-20-szoros különbség volt kimutatható a nyugateurópai és a hazai értékek között, addig ez az arány napjainkra 6-8-szorosra mérséklődött. A növekedés dinamikája tehát bíztató, nemzetközi lemaradásunkat ezen a területen mindössze 4-5 évre teszik a szakemberek (Straub 2000).

Az Internet használók száma és a teljes lakossághoz viszonyított aránya azonban lényegesen elmarad a fejlett európai országok hasonló adataitól (1. táblázat). A viszonylag alacsony érték több okra vezethetö vissza. A legfontosabb okokat az alábbiakban foglalhatjuk össze:

- a fejlett országokhoz képest alacsony életszínvonal,

- a számítástechnikai berendezések átlagfizetésekhez mérten magas ára,

- az internetes szolgáltatás magas ára (modemes kapcsolat esetén európai tekintetben is magas telefondijak),

- az internetes hálózat teljes körü (fizikai) elérhetőségének hiánya,

- a számítástechnikai kultúra alacsony szintje,

- a számítástechnikai ismeretek hiánya,

- a társadalmi adaptivitás alacsony foka,

- életkori sajátosságok (magas az időskorú népesség aránya, ez a korosztály elenyésző mértékben veszi igénybe ezt a technikát),

- a magyar nyelvü tartalomszolgáltatás szük keresztmetszete,

- idegen nyelvek ismeretének hiánya. 
Az információs-kommunikációs technikák terjedésének regionális különbségei Magyarországon. Tér és Társadalom, 14. 2000. 2-3. 159-172. p.

TÉT XIV. évf. 2000 2-3

A lakótelepek helyzete...

167

\section{TÁBLÁZAT}

Az Internetet használók száma néhány európai országban

(Number of Internet Users in Some European Countries)

\begin{tabular}{|c|c|c|c|c|}
\hline Ország & Dátum & Adat (fö) & $\begin{array}{l}\text { A népesség } \\
\text { \%-ában }\end{array}$ & Forrás \\
\hline Oroszország & 1998. december & 1,2 millió & 0,8 & IDC Research \\
\hline Görögország & 1998. január & 111000 & 1,0 & IDC Research \\
\hline Törökország & 1997. május & 600000 & 1,0 & Nua becslés \\
\hline Lengyelország & 1997. november & 700000 & 1,8 & Nua becslés \\
\hline Portugália & 1998. január & 188000 & 1,9 & IDC Research \\
\hline Csehország & 1998. január & 270000 & 2,6 & IDC Research \\
\hline Magyarország & 1999. március & 500000 & 4,96 & Fehér könyv \\
\hline Franciaország & 1998. május & 2,5 millió & 5,2 & Mediangles \\
\hline Ausztria & 1998. augusztus & 442000 & 5,5 & IDC Research \\
\hline Spanyolország & 1999. március & 2,75 millió & 7,7 & AIMC \\
\hline Olaszország & 1999. június & 5 millió & 7,96 & $\begin{array}{l}\text { Osservatorio Internet } \\
\text { Italia }\end{array}$ \\
\hline Szlovákia & 1998. szeptember & 510000 & 9,5 & Net Projekt \\
\hline Észtország & 1998. október & 152000 & 10,0 & BMF Gallup Media \\
\hline Németország & 1999. március & 8,4 millió & 10,0 & GfK \\
\hline Írország & 1999. június & 380000 & 13,5 & Amarach Consulting \\
\hline Hollandia & 1999. március & 2,3 millió & 13,7 & ProAcive \\
\hline Belgium & 1999. február & 1,4 millió & 16,0 & Initiative Media Brussels \\
\hline Svájc & 1998. szeptember & 1,2 millió & 16,2 & WEFN \\
\hline Nagy-Britannia & 1998. december & 10,6 millió & 18,0 & NOP Research Group \\
\hline Finnország & 1999. majus & 1,6 millió & 32,0 & $\begin{array}{l}\text { Business Arena Stock- } \\
\text { holm }\end{array}$ \\
\hline Dánia & 1999. május & 1,7 millió & 34,0 & $\begin{array}{l}\text { Business Arena Stock- } \\
\text { holm }\end{array}$ \\
\hline Norvégia & 1999. május & 1,6 millió & 36,3 & $\begin{array}{l}\text { Business Arena Stock- } \\
\text { holm }\end{array}$ \\
\hline Svédország & 1999. május & 3,6 millió & 40,9 & $\begin{array}{l}\text { Business Arena Stock- } \\
\text { holm }\end{array}$ \\
\hline Izland & 1998. december & 121074 & 45,0 & PWC \\
\hline
\end{tabular}

Forrás: http://www.nua.ie/surveys/how many online/europe.html 1999.

A felsorolt problémák ellenére a felhasználói szám jelentős növekedését prognosztizálhatjuk, melyet megítélésünk szerint négy fö tényező fog a jövőben erősiteni. A legfontosabb tényezőnek talán az emelkedő életszínvonalat tekinthetjük, de ugyanilyen jelentőségü lehet a távközlési piac liberalizálása következtében csökkenő telefondíjak ösztönző hatása, az informatikai oktatás folyamatos elterjedése, szinvonalának emelése, vagy a műszaki újítások következtében megjelenő, s egyre inkább elterjedỏ alternatív - a telefonkábelnél olcsóbb (pl. kábel TV, PLC), illetve vezetékek fektetését nem igénylő mobil - hálózatok. 


\section{A magyarországi internetes számítógépek területi elhelyezkedése}

Az Információs Társadalom (IT) kiépüléséhez vezető úton - az élesedő gazdasági és területi versenyben - az egyes emberek, a társadalmi és gazdasági szervezetek, valamint a különböző területi szintek (önkormányzatok, kistérségek, régiók) információkkal való ellátása, az információkhoz történő hozzáférés biztosítása, ezen keresztül az esélyegyenlöség megteremtése, növelése meghatározó jelentőségü folyamat. A modern kor embere számára ma már nélkülözhetetlenek az információátvitel és -feldolgozás különböző eszközei, legyen szó akár munkáról, szabadidő eltöltésérỏl, társadalmi-gazdasági kapcsolatok szervezéséről, oktatásról, vagy egészségügyi ellátásról. Hazai és nemzetközi tapasztalatok azt mutatják, hogy minél intenzívebben épülnek be ezek az információs technikák, technológiák egy terület társadalmának életébe (minél több és pontosabb információ birtokába jut), annál sikeresebbnek és életképesebbnek mutatkoznak a területek, régiók között zajló versenyben. Éppen ezért nagyon fontos, hogy pontosan meg tudjuk határozni az Internet-alapú számítógépek terjedésének és elhelyezkedésének törvényszerủségeit, hiszen ezek a számítógépek igen jelentős innováció-hordozók. Az egyes területeken történő tömeges megjelenésük innovációs gócokról tájékoztathat, esetleg új innovációs területeket jelölhetnek ki, hiányuk pedig adaptációs, kommunikációs vagy egyéb fejlödésbeli problémákat (gazdasági, társadalmi) mutathatnak, illetve vetíthetnek elö. A kérdéskör fontosságát és új területi aspektusait jól példázza, hogy az 1990-es évek folyamán a számítógépek és a telematika terjedésének ágazati és területi sajátosságaival, következményeivel, az információs technikák területfejlesztésben betöltött szerepével a hazai kutatók is egyre élénkebben kezdtek el foglalkozni (Erdősi 1992; Nagy 1997; Rechnitzer 1990; Ruttkay 1992; Tinner 1998).

A számítástechnikai ágazat, $\mathrm{s}$ ezen belül a számítógépek terjedésének, területi eloszlásának és pontos számának nyomon követése nem egyszerü feladat. Az 1980-as, majd a kilencvenes évek első felében a kutatók - a megfelelő területi statisztikák hiánya miatt - a számítógépek térbeli terjedését és eloszlását csak nagyon nehezen, leginkább közvetett módszerekkel (pl. a számítógép-állomány kapacitása alapján, vagy a számítástechnikai folyóiratok előfizetői alapján) próbálták nyomon követni (Rechnitzer 1993). A hálózatba nem kötött számítógépek területi eloszlásának vizsgálatára vonatkozóan - néhány újabb megközelítési módot (pl. a számítástechnikai vállalkozások egyes településekre jutó száma, vagy a számítástechnikai vállalkozás bevételei alapján való következtetés a terület számítástechnikai ellátottságára) leszámítva - a kilencvenes évek második felében sem sikerült pontosabb módszereket kidolgozni. Valamivel kedvezőbb a helyzet, ha az Internet-alapú számítógépek számát és térbeliségét próbáljuk megvizsgálni. A hálózatba bekötött számítógépek számának és területi eloszlásának meghatározása érdekében két nagy adatbázisra támaszkodtunk. Az egyik - az Eunet által létrehozott nemzetközi szervezet - a RIPE (Reseaux IP Europeens) domain nevek regisztrációját is tartalmazó adatbázisa, a másik pedig a magyarországi hálózati információs központ „,hu” kiterjesztésü domain név nyilvántartása volt. Az 1998 végén elvégzett leválogatás során 5264 db 
„,hu” kiterjesztésủ domain név szerver területi elhelyezkedését sikerült meghatározni. ${ }^{15}$ A magyarországi szerverek területi eloszlására jellemzö, hogy a településállomány mindössze 7\%-ában, 260 településen - melyek közül valamivel több, mint $50 \%$ (137 db település) volt városi jogállású - voltak megtalálhatók. A szerverek számának eloszlásában nagyon erös városi koncentrációt figyelhetünk meg. A koncentráció mértékére jellemzö, hogy az $5264 \mathrm{db}$ domain szerverböl $4866 \mathrm{db}$ müködött városokban, ez az összes szerver gép 92,4\%-át jelentette. Ezen belül is Budapest aránya kiugró $(71,68 \%)$, de meghatározó a megyei jogú városok aránya $(16,62 \%)$ is (2. táblázat).

\section{TÁBLÁZAT}

A domain név szerverek települési szóródása 1998 végén (Distribution of Domain Name Servers by Settlement Categories)

\begin{tabular}{lccc}
\hline \multicolumn{1}{c}{ Települések } & $\begin{array}{c}\text { Települések száma } \\
(\mathrm{db})\end{array}$ & $\begin{array}{c}\text { Szerverek száma } \\
(\mathrm{db})\end{array}$ & $\begin{array}{c}\text { Százalékos meg- } \\
\text { oszlás (\%) }\end{array}$ \\
\hline Budapest & 1 & 3773 & 71,68 \\
Megyei jogú városok & 22 & 875 & 16,62 \\
Egyéb városok & 114 & 218 & 4,14 \\
Községek & 123 & 398 & 7,56 \\
Összesen & 260 & 5264 & 100,00 \\
\hline
\end{tabular}

Forrás: www.nic.hu alapján egyéni számítás.

Látható tehát, hogy települési szinten a társadalmi, gazdasági szempontból elönyösebb helyzetben lévő, nagyobb adaptációs és innovációs képességgel rendelkezö, $\mathrm{s}$ nem utolsó sorban a jelentősebb népességszámmal bíró településeken találhatók meg legnagyobb számban az Internet végpontokat kiszolgáló szervergépek. ${ }^{16}$ Ezen belül is a szerverek területi eloszlása elsösorban a gazdasági aktivitással mutat szoros korrelációt. Erre utal az a tény is, hogy a bejegyzett szervergépek több mint $75 \%$-a valamilyen üzleti tevékenységhez kötődik, nagyobb részt a szolgáltatási és a kereskedelmi szférához.

A nagyobb területi egységek (megyék, régiók) vizsgálatánál is kitủnt, hogy a szerver számítógépek száma jó egyezést mutat a megyék általános gazdasági és társadalmi fejlettségével (3. táblázat). Hasonló képet kapunk, ha a magyarországi Internet végpontok (úgynevezett host gépek) térbeli elhelyezkedését próbáljuk nyomon követni. Megfelelő területi nyilvántartás hiányában azonban nem tudunk olyan pontos képet rajzolni, mint a domain szerverek esetében. Azt azonban tudjuk, hogy egy szervergép átlagosan 12-15 db Internet végpontot szolgál ki, így a Magyarországon 1998 végén üzemben lévő több mint 100000 host számítógép 70-80\%-ának területi elhelyezkedése bizonyíthatóan, további 10-15\%-a nagy valószínúséggel egybeesett a szervergépek területi elhelyezkedésével.

A fentiekben vázolt informatikai infrastruktúra és számítógépes háttér területi elhelyezkedése egy fontos, a térszerkezetet, területi fejlödést is meghatározó jelenségre hívja fel a figyelmet. Az 1990-es években a távközlési és informatikai infrastruktúránk, információs-adatkommunikációs technikánk, technológiánk - a nem- 
zetközi trendekhez hasonlóan - dinamikusan, ugyanakkor rendkívül koncentráltan fejlödött. A fejlesztési folyamat a piac igényeinek (szükségleteinek) megfelelöen, döntően a nagyobb népességet tömörítő gazdasági, valamint oktatási és kutatási központjainkban valósult meg, növelve ezzel az országon belüli - pl. infrastrukturális ellátottságban, gazdasági fejlettségben, társadalmi lehetőségekben - amúgy is meglévő területi aránytalanságokat. Különösen helytállónak tủnnek ezek a megállapítások, ha figyelembe vesszük a legújabb felmérések részeredményeit, amelyek a 2000. márciusi állapotokat tükrözik. A 12450 db nyilvántartásba vett ,,hu” kiterjesztésủ domain név szerver közel két és félszerese az elöző felmérésben szerepelt szervergép számnak. (Látható tehát, hogy a növekedés igen dinamikus volt az elmúlt közel másfél évben). Felmérésünkben eddig újabb 2000 címet sikerült feldolgoznunk, s ennek alapján kijelenthető, hogy a területi aránytalanságok tovább fokozódtak. Az új bejegyzéseknek tởbb mint 95\%-a azokon a településeken jött létre, amelyeken már müködött hálózati szerver. Tovább nött a városok aránya, $\mathrm{s}$ érdekességként meg kell jegyezni, hogy az újabb szervergépek több mint $80 \%$-a gazdasági tevékenységhez (termelés, szolgáltatás, kereskedelem) kötődik, ami az amúgy is jobb helyzetben levő ipari területek erösödő dominanciáját mutatja.

\section{TÁBLÁZAT}

A DNS domain szerverek megyei eloszlása 1998 végén (Distribution of DNS Domain Servers by Counties)

\begin{tabular}{lcc}
\hline \multicolumn{1}{c}{ Megye } & Találatok száma $(\mathrm{db})$ & A találatok megoszlása (\%) \\
\hline Budapest & 3773 & 71,67 \\
Baranya & 95 & 1,81 \\
Bács-Kiskun & 77 & 1,47 \\
Békés & 49 & 0,93 \\
Borsod-Abaúj-Zemplén & 79 & 1,51 \\
Csongrád & 141 & 2,68 \\
Fejér & 115 & 2,19 \\
Gyỏr-Moson-Sopron & 117 & 2,23 \\
Hajdú-Bihar & 103 & 1,95 \\
Heves & 53 & 1,00 \\
Komárom-Esztergom & 62 & 1,17 \\
Nógrád & 29 & 0,56 \\
Pest & 232 & 4,40 \\
Somogy & 59 & 1,13 \\
Szabolcs-Szatmár-Bereg & 42 & 0,79 \\
Jász-Nagykun-Szolnok & 53 & 1,00 \\
Tolna & 31 & 0,58 \\
Vas & 37 & 0,71 \\
Veszprém & 68 & 1,29 \\
Zala & 49 & 0,93 \\
Összesen & 5264 & 100,00 \\
\hline
\end{tabular}

Forrás:wwww.nic.hu alapján egyéni számítás. 


\section{Záró gondolatok}

Tanulmányunkban megpróbáltuk áttekinteni az egyre dinamikusabban fejlődő magyarországi információs-kommunikációs ágazat müszaki-technikai alapjainak területi kiépülését $\mathrm{s}$ az elmúlt egy évtized jelentősebb változásait. Ez az állapotfeltárás mintegy előkészíti, és alapját képezi annak a hosszabb kutatómunkának, amely az Információs Társadalom kiépülésének, nemzetközi és hazai elterjedésének törvényszerüségeit, következményeit, valamint számos vetületét - müszaki, területi, társadalmi, gazdasági - próbálja a jövőben megvilágítani és a szélesebb szakmai közönség elé tárni, annak reményében, hogy számos érdekes és új kutatási eredménnyel fogja gazdagítani a területi tudomány diszciplínáját.

\section{Jegyzetek}

${ }^{1}$ TERENA (Trans-European Research and Education Networking Association): Összeurópai Kutató és Oktatási Hálózati Társulás. A legfontosabb európai hálóżati szervezet.

DANTE (Delivery of Advanced Networking Technology to Europe): Összeurópai szolgáltató központ. CEENet (Central and Eastem European Networking Association): Közép- és Kelet-Európai Hálózati Társulás.

ISOC (Intemet Society): az Intemet technikai, szervezési, szabványositási, kultúrateremtési szerepet játszó nemzetközi szervezete.

2 A MATÁV csak 1991-ben indította el az optikai gerinchálózat kialakítását célzó programját. A program eredményeként 1993-ban adták át az optikai gerinchálózatot $(3400 \mathrm{~km}, 560 \mathrm{kbit} / \mathrm{s}$ átviteli sebesség).

${ }^{3}$ A COCOM elöirások miatt csak 1989-ben érkezett az országba az első világszínvonalú digitális központ. A korlátozások megszunnése azonban nem jelentette automatikusan a digitális központok gyors és nagyarányú elterjedését, ami elsősorban a magas beszerzési árral magyarázható.

${ }^{4}$ A gyors fejlesztést egyrészt a koncessziós szerződésekben meghatározott feltételek, másrészt a potenciális felhasználói kör (,academic” szféra, lakosság, magyarországi gazdasági társaságok, külfơldi érdekeltségü vállalkozások, közigazgatás stb.) megjelenö igényei sürgették.

${ }^{5}$ A koncessziós telefontársaságok 1994 és 1996 között megközelítőleg 1 millió ủj vonalat helyeztek üzembe, így 1996 végén 2651000 távbeszélö fövonalat tartott nyílván a statisztika. 1996 és 2000 között is számottevỏ volt a fejlödés, ennek köszönhetöen a fövonalszám ma hozzávetölegesen 3720000.

${ }^{6} 1999$ végén a MATÁV kb. $4000 \mathrm{~km}$, míg a többi LTO több mint $3000 \mathrm{~km}$ hosszú optikai hálózattal rendelkezett.

${ }^{7}$ A PLC (Powerline Communication) hálózatot $2 \mathrm{Mbit} / \mathrm{s}$ sávszélességüre tervezik, ami a ma használatos ISDN vonalaknál is hússzor gyorsabb, s mivel újabb infrastruktúra kiépitést nem igényel, valamint az üzemeltetése is lényegesen olcsóbb, mint a hagyományos telefonkábeleké, ezért nagy jövöt jósolnak ennek a technikának a távközlési szakemberek.

${ }^{8}$ A mobil telefon elöfizetök száma 1999 végén a Westel 900 GSM társaságnál 850000 fö, a Pannon GSM-nél 670000 fö, mig a Westel Rádiótelefon Kft.-nél (450 Mhz) 100000 fö volt. A Vodafon ügyfélköréről pontos adatok még nem állnak rendelkezésünkre, a szolgáltatást 1999. november 30-án kezdték el.

${ }^{9}$ Egy megfelelő színvonalú kábeltévés rendszer egy időben 60 TV csatoma átvitelére alkalmas. Egy csatományi helyen max. $30 \mathrm{Mbit} / \mathrm{s}$ adatătviteli sebesség érhetô el (a kábeltévés szolgáltatók általában $64 \mathrm{Kbit} / \mathrm{s}$ és $8 \mathrm{Mbit} / \mathrm{s}$ közötti sávszélességet biztosítanak elöfizetöiknek), tehát nagyságrendekkel gyorsabbak, nagyobb kapacitásúak, mint a ma használatos telefonvonalak ( $56 \mathrm{Kbit} / \mathrm{s}$ ).

${ }^{10}$ A kábeltévén keresztül nyújtott Intemet szolgáltatás elöfizetőinek száma Magyarországon kb. 4000 fö.

11 1999. évi LXVI. törvény (a távközlésról szóló 1992. évi LXXII. törvêny módositása).

12 A Ripe (Reseaux IP Europeens) Intemetes számítógépekkel foglal kozó adatbázisa alapján, Magyarországon 2000. április 14-én 18496 domain név szervert és 114963 Intemet végpontot (host) tartottak nyilván. Duplikációkkal a hostok száma még ennél is nagyobb (155912 db) volt. 
${ }^{13}$ Az adatok 1998, december 31-iek.

${ }^{14}$ Sajnos ez a sávszélesség még nem általános Magyarországon, a legtöbb HBONE regionális központ még most is csak $512 \mathrm{Kbi} / \mathrm{s}-0$ (Békéscsaba, Eger, Kecskemét, Szombathely), vagy még ennél is kisebb teljesitményủ hálózattal rendelkezik (pl. Kaposvår, Keszthely, Salgótarján, Sopron, Szekszárd, Székesfehérvár, Szolnok).

15 A magyarországi szervergépek száma ebben az időszakban lényegesen magasabb lehetett, hiszen a nyilvántartásban nem szerepeltek a Magyarorszågon mủködő ,,com” és „,net" kiterjesztésủ szervergépek.

${ }^{16}$ Érdemes megfigyelni, hogy a szervergépek számának alakulása jól követi a településhierarchiát.

\section{Irodalom}

Bakonyi P.-Bálint L. (1996) Kutatási-felsőoktatási hálózatok: az információs társadalom elófutárai. Info-Társadalomtudomány. 38. 31-45. o.

Castells, M. (1996) Rise of the Network Society. Oxford, Blackwell.

Ehrlich É. (1998) Infrastruktúrák és szolgáltatások Magyarországon. - Info-Társadalomtudomány. 43. 7-22. o.

Erdösi F. (1992) Telematika. Budapest, Távközlési Kiadó.

Goddard J.B.-Gillespie A.E. (1986) Advanced telecommunications and regional economic development. - The Geographical Journal. 3. 383-397. o.

Nagy G. (1997) Kommunikációs szektor az Északnyugat-Dunántúl térségében. - Tér és Társadalom. 1. 125-146. o.

Rechnitzer J. (1990) A számítástechnika területi terjedése Magyarországon. Budapest-Györ, Ts-2/2 Program Iroda.

Rechnitzer J. (1993) Szétszakadás vagy felzárkózás. - A térszerkezetet alakító innovációk. Győr, MTA RKK.

Ruttkay É. (1992) Az információgazdaság térbeli terjedésének néhány jellemöje hazánkban. - KutatósSzervezési Tájékoźtató. 3-4. 109-120. o.

Straub E. (2000) www.internetkonferencia.hu

Tinner T. (1998) Távközlés és informatika. - Ezredforduló. 4. 12-17. o.

Vámos T. (1981) Az MTA 1981. évi közgyúlésén tartott elöadásának rövidített változata. - Ezredforduló. 1. 29-33. o.

\section{REGIONAL DISPARITIES IN THE SPREADING OF INFORMATION-COMMUNICATION TECHNOLOGIES IN HUNGARY}

\section{IMRE KANALAS}

In the $2^{\text {nd }}$ half of the 80 's, but especially in the middle of the 90 's after the privatisation of the telecommunications sector the informational-communicational technology began to develop dynamically in Hungary. The annual development of this branch is faster than the other ones. Due to the technical-technological development, the level of our telecommunication-datacommunication infrastructure is good in comparison with other European countries. The network digitalisation that is needed for high level services is more than $80 \%$. Due to the increasing demand, the capital flowing into the branch and the suitable economical and political conditions a 3-level information network have been made (academic network, secondary school network, and commercial network). Network developments have been made especially in bigger university and economic centres according to the economical needs in a dynamic and concentrated way as in the international trends. More concentration can be seen in the territorial placement of Internet servers, which has increased the territorial inequality, e.g. in infrastructure facilities, economic development and social opportunities. 